\title{
COMPARITIVE EFFECT OF SOME PLANTER FURROW OPENERS AND SEED COVERING DEVICES ON SOME SOIL PROPERTIES AND CROPS PRODUCTIVITY
}

\author{
Khater, M. M. I.*
}

\begin{abstract}
Two field experiments were carried out at a private farm in East Qantara; Ismailia Governorate, Egypt during two cultivated successive seasons (summer and winter) of 2011. The experiments aimed to compare the effect of planter furrow openers (single disc, double disc, hoe and shoe) and seed covering devices (press wheel, paddles and drag chains) on some soil physical properties and energy consumed of seeding operation as well as seed germination and biological yield of corn silage (Zea mays) and pea (Pisum sativum ) on sandy loam soil under sprinkler irrigation system. The comparative effect of studied furrow opener devices on the values of soil bulk density of cultivated surface soil depth (0- $15 \mathrm{~cm})$ under both crops in this study were ranked as hoe > shoe > single disc > double disc. While, the comparative effect of studied covering devices on the soil bulk density of cultivated surface soil depth values were ranked as wheel > paddles > drag chains. Under studied treatments, the lowest of soil bulk density value was 1.40 and $1.38 \mathrm{~g} / \mathrm{cm}^{3}$ for double disc furrow with drag chains treatment at 40 and 3 days after the planting date of the corn silage, respectively. The obtained results showed that soil porosity values at 40 days of the planting date of the corn silage and pea plants were lower than after 3 days of planting under studied treatments. Under the same treatments, the soil porosity highest value was about 47.92 and $47.17 \%$ for double disc furrow with drag chains treatment after 3 and after 40 days of the planting date for corn silage, respectively. At the same treatments, the highest value of soil porosity was 50.19 and $49.43 \%$ for double disc furrow opener with drag chains treatment after 3 and after 40 days of the planting date of the pea plants, respectively. Soil water content takes the same trend of obtained results of soil bulk density and soil porosity using the furrow opener devices, while it takes the opposite trend with using covering devices at the same treatments.
\end{abstract}

*Soil Conservation Department, Desert Research Center, Cairo, Egypt 
The obtained results revealed that the consumed energy values of corn silage varied 35.65 to 51.02 and 31.93 to $45.73 \mathrm{~kW}$. $\mathrm{h} /$ fed for corn silage and pea plants under studied treatments, respectively. Generally the single disc furrow openers was less double disc, shoe and hoe furrow openers respectively. The biological yield values of corn silage varied between 39260 to $20410 \mathrm{~kg} / \mathrm{fed}$ and 5299 to $815 \mathrm{~kg} / \mathrm{fed}$ for pea plants under studied treatments, respectively. Also, the obtained results showed that the highest value of biological yield was 39260 and $5299 \mathrm{~kg} / \mathrm{fed}$ at double disc furrow with wheel treatment for the corn silage and pea plants under the same treatments, respectively. The using double disc furrow opener with wheel treatment at seeding operation is preferable treatment for increasing the productivity of studied crops.

Keywords: furrow openers, seed covering devices, soil physical properties, consumed energy of seeding operation, corn silage yield, pea yield.

\section{INTRODUCTION}

oil in new reclaimed areas need special planting machines used to meet the needs of crop producers seeking to take advantage of crop production. Planting into soils with surface residues has become the identifying characteristic of conservation tillage systems. Robert, et al., (2009) reported that no-till planters and drills must be able to cut and handle residue, penetrate the soil to the proper seeding bed, and establish good seed soil contact. Moist soils covered with residue, which may also be wet, provides an ideal seed germination environment, such conditions can make it difficult to cut through residue. In contrast, hard and dry conditions may also prevail. This is especially common when no-tilling soybean into wheat stubble during the hot, dry months of June and July. Although cutting residue is easier during dry conditions, it is more difficult to penetrate the hard, dry soils. Rainbow, (2008) showed that planting depth is a major determinant of seedling emergence and hence one of the most important operational requirements of a planting machine. Murray, et al., (2006) clarified that the optimum planting depth has two essential components: the depth of the furrow relative to the original soil surface and the depth of soil covering the 
seed. The depth from the original soil surface has implications for level of moisture availability to the seed. The depth of soil cover over the seed has implications for emergence. Adequate moisture in the surface layer, furrow depth can be set to optimize depth of cover for emergence. However, when it is necessary to plant deeper to ensure seed is placed in moist soil the resultant depth of cover can limit emergence. Chen et al., (2006) found that press wheels can also be used to modify the depth of cover in addition to firming the seedbed, particularly where full-width cultivation for weed control is performed at time of planting. Under these conditions, the press wheels substantially reduce the depth of cover and give a higher degree of uniformity in the depth of cover. Chaudhuri, (2001) showed that furrow opener is an important component of planter machines. In general, a furrow opener cuts a furrow and allows the seeds or seedlings to be deposited before being partially covered with soil. The types of furrow openers used vary with soil and operating conditions. The common types of furrow openers used for conventional tillage are hoe, shovel, shoe, runner, single disc, double disc, chisel and inverted $\mathrm{T}$ furrow openers. Common types of furrow openers used for minimum and no tillage systems are hoe, chisel, winged chisel, inverted $\mathrm{T}$ and triple disc furrow openers. He added that, some of the furrow openers are used in seed drills, each opener having a single seed tube. Magdy, (1998) found that the double disc opener was better than single disc and runner opener, while the $\mathrm{V}$ shape was the best to cover cotton seeds on ridge planting system, the previous operating treatments were observed on sandy soil.

The objectives of the present study are to investigate the comparative effect of furrow openers and seed covering devices on some soil physical properties and consumed energy of planting operation as well as seed germination and biological yield of corn silage and pea plants under sprinkler irrigation system.

\section{MATERIALS AND METHODS}

Two field experiments were carried out at a private farm in newly reclaimed area East Qantara; Ismailia Governorate, Egypt during two successive seasons (summer and winter) of 2011. The Experimental farm site is located at latitude of $30^{\circ} 28^{\prime} 22^{\prime \prime} \mathrm{N}$ and longitude of $32^{\circ} 22^{\prime} 46^{\prime \prime} \mathrm{E}$. 
The experiments aimed to compare the effect of furrow openers and seed covering devices on some soil physical properties and energy consumed of planting operation by planter machine as well as seed germination and yield of corn silage (Zea mays cv., O-35) and pea (Pisum sativum cv., Little Marvel) under sprinkler irrigation system during summer and winter seasons, respectively. The soil of experimental farm was classified as sandy loam (71.60\% sand, $16.22 \%$ silt and $12.18 \%$ clay) with 1.68 $\mathrm{g} / \mathrm{cm}^{3}$ bulk density. Particle size distribution and bulk density of soil were determined accordingly, Kulte, (1986). The layout of the experiment was a completely randomized design with three replicates. The replicate area was $50 \mathrm{~m}^{2}(2.5 \times 20 \mathrm{~m})$. The agronomic practices including weed and pest control followed as recommended of corn silage and pea productions. Each experiment consisted of 12 treatments combined between the four furrow openers (single disc, double disc, shoe and hoe) and three seed covering devices (wheel, paddles and drag chains) illustrated in Fig.(1), and as follows:
A: Single disc furrow opener + wheel
B: Single disc furrow opener + paddles
C: Single disc furrow opener + drag chains
D: Double disc furrow opener + wheel
E: Double disc furrow opener + paddles
F: Double disc furrow opener + drag chains
$\mathrm{G}$ : Shoe furrow opener + wheel
$\mathrm{H}$ : Shoe furrow opener + paddles
I: Shoe furrow opener + drag chains
$\mathrm{J}$ : Hoe (chisel) furrow opener + wheel
$\mathrm{K}$ : Hoe (chisel) furrow opener + paddles, and
L: Hoe (chisel) furrow opener + drag chains.

A pneumatic planter was used for studied treatments with 5 furrow openers, working width of $380 \mathrm{~cm}$ and working speed of $4.2 \mathrm{~km} / \mathrm{h}$.

Soil bulk density, $\mathrm{g} / \mathrm{cm}^{3}$, and water content, \%, at surface soil depth $(0$ $15 \mathrm{~cm})$ determined at $3\left(\mathbf{1}^{\mathbf{s t}}\right)$ and 40 days after the planting date $\left(\mathbf{2}^{\mathbf{n d}}\right)$ for each treatment using core method, Klute, (1986) and estimated soil total porosity by the following formula:

$$
\mathrm{P}=100 *\left(1-\rho_{\mathrm{b}} / \rho_{\mathrm{s}}\right)
$$


Where $\mathrm{P}$ is the total porosity, $\%, \rho_{\mathrm{b}}$ is soil bulk density, $\mathrm{g} / \mathrm{cm}^{3}$ and $\rho_{\mathrm{s}}$ is soil particles density, $\mathrm{g} / \mathrm{cm}^{3}$.

A $90 \mathrm{hp}(66.24 \mathrm{~kW})$ tractor was used for the minimum tillage operation by chisel plow for studied treatments. The consumed energy values of planting operation alone under studied treatments were estimated accordingly, Hunt, (1983). Seed germination percent and yield of corn silage and pea plants at harvesting were determined for each treatment.

Analysis of variance by 1 Way Completely Randomized was used to test the degree of variability among the obtained data. Least significant difference (LSD) test was used for the comparison among treatments means, Steel and Torrie (1980).

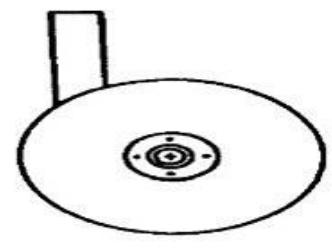

Single disc furrow opener

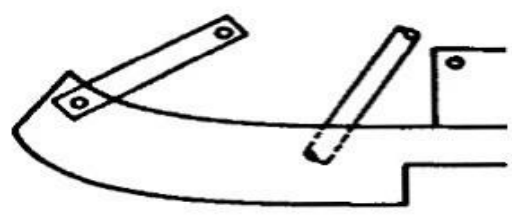

Shoe furrow opener

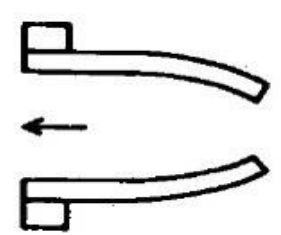

Paddles

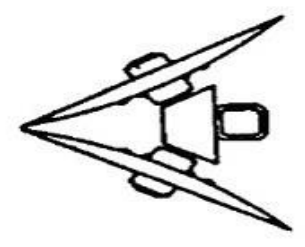

Double disc furrow opener

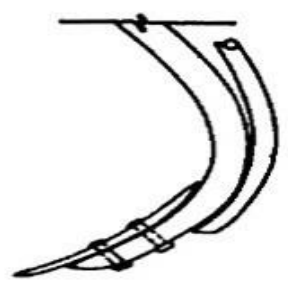

Hoe (chisel) furrow opener

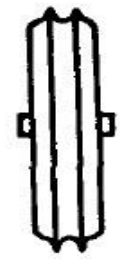

Wheel

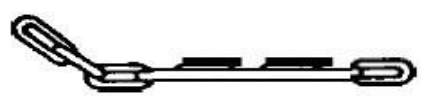

Drag chains

Fig. (1): The types of studied furrow openers and seed covering devices in the two experiments. 


\section{RESULTS AND DISCUSSION}

\section{Effect of furrow openers and seed covering devices on some soil physical properties.}

The results in Table (1) showed that the cultivated surface soil depth (0 $15 \mathrm{~cm}$ ) bulk density, $\mathrm{g} / \mathrm{cm}^{3}$, at 3 and 40 days after the planting date for corn silage and pea which affected by combined between the furrow openers and seed covering devices, the soil bulk density obviously were lower than that the initial bulk density of the experimental soil. These lower could be attributed to furrow openers and seed covering devices caused the disturbing of soil aggregates and decreasing of soil compaction consequently, decreased soil bulk density. The soil bulk density values at 3 and 40 days after the planting date of the planting date of corn silage growth season under studied treatments ranged between $1.38-1.60$ and $1.40-1.66 \mathrm{~g} / \mathrm{cm}^{3}$, respectively. However, these values at 3 and 40 days after the planting date for pea growth season at the same treatments varied from 1.32 to 1.53 and 1.34 to $1.59 \mathrm{~g} / \mathrm{m}^{3}$, respectively.

The comparative effect of the furrow opener devices on soil bulk density of cultivated surface soil depth during growth season of studied crops appeared that the hoe furrow opener had the highest soil bulk density values, Table (1). The soil bulk density of cultivated surface soil depth values at studied furrow opener devices under studied crops in this study were ranked as hoe $>$ shoe $>$ single disc $>$ double disc. This trend might be attributed to the hoe and shoe furrow openers increased the soil compaction, thus the increasing of soil bulk density values. The comparative effect of the seed covering devices on the soil bulk density of cultivated surface soil depth under studied crops growth seasons appeared that the wheel had the highest soil bulk density values and ranked as wheel $>$ paddles $>$ drag chains. On the other hand, the results in Table (1) revealed that soil bulk density values after 40 days of the planting date of the corn silage and pea plants were higher than that obtained at the first irrigation after 3 days under studied treatments. This higher could be due to the reorientation of soil particles and increased soil compaction resulted by the wetting and drying cycles during 40 days from planting days, consequently, increased soil bulk density. 
Table (1): Effect of furrow openers and seed covering devices on some soil physical properties during studied crops growth season.

\begin{tabular}{|c|c|c|c|c|c|c|c|c|c|c|c|c|}
\hline \multirow{4}{*}{ Treatments } & \multicolumn{12}{|c|}{ Soil physical properties under studied crops } \\
\hline & \multicolumn{6}{|c|}{ Corn silage } & \multicolumn{6}{|c|}{ Pea plant } \\
\hline & \multicolumn{2}{|c|}{$\begin{array}{c}\text { Soil bulk } \\
\text { density } \\
\text { g/cm }\end{array}$} & \multicolumn{2}{|c|}{$\begin{array}{c}\text { Soil } \\
\text { porosity } \\
\% \\
\end{array}$} & \multicolumn{2}{|c|}{$\begin{array}{c}\text { Soil water } \\
\text { content } \\
\% \\
\end{array}$} & \multicolumn{2}{|c|}{$\begin{array}{c}\text { Soil bulk } \\
\text { density } \\
\text { g/cm }\end{array}$} & \multicolumn{2}{|c|}{$\begin{array}{c}\text { Soil } \\
\text { porosity } \\
\%\end{array}$} & \multicolumn{2}{|c|}{$\begin{array}{c}\text { Soil water } \\
\text { content } \\
\% \\
\end{array}$} \\
\hline & $1^{\text {st }}$ & $2^{\text {nd }}$ & $1^{\text {st }}$ & $2^{\text {nd }}$ & $1^{\text {st }}$ & $2^{\text {nd }}$ & $1^{\text {st }}$ & $2^{\text {nd }}$ & $1^{\text {st }}$ & $2^{\text {nd }}$ & $1^{\text {st }}$ & $2^{\text {nd }}$ \\
\hline $\mathbf{A}$ & 1.49 & 1.51 & 43.77 & 43.01 & 17.60 & 25.34 & 1.43 & 1.44 & 46.03 & 45.66 & 21.12 & 29.94 \\
\hline B & 1.47 & 1.51 & 44.52 & 43.01 & 15.29 & 22.00 & 1.41 & 1.44 & 46.79 & 45.66 & 18.34 & 25.72 \\
\hline $\mathbf{C}$ & 1.46 & 1.49 & 44.90 & 43.77 & 13.19 & 18.98 & 1.40 & 1.43 & 47.16 & 46.03 & 15.82 & 21.67 \\
\hline D & 1.46 & 1.48 & 44.90 & 44.15 & 18.78 & 27.03 & 1.40 & 1.42 & 47.16 & 46.41 & 22.53 & 31.26 \\
\hline $\mathbf{E}$ & 1.43 & 1.48 & 46.03 & 44.15 & 17.79 & 25.60 & 1.37 & 1.42 & 48.30 & 46.38 & 21.34 & 30.86 \\
\hline $\mathbf{F}$ & 1.38 & 1.40 & 47.92 & 47.16 & 14.75 & 21.24 & 1.32 & 1.34 & 50.18 & 49.43 & 17.70 & 30.40 \\
\hline G & 1.53 & 1.60 & 42.26 & 39.62 & 11.71 & 16.86 & 1.46 & 1.53 & 44.90 & 42.26 & 14.05 & 21.23 \\
\hline $\mathbf{H}$ & 1.52 & 1.58 & 42.64 & 40.37 & 11.42 & 16.44 & 1.45 & 1.51 & 45.28 & 43.01 & 13.70 & 20.87 \\
\hline I & 1.51 & 1.58 & 43.01 & 40.37 & 9.63 & 13.86 & 1.44 & 1.51 & 45.66 & 43.01 & 11.55 & 20.75 \\
\hline $\mathbf{J}$ & 1.60 & 1.66 & 39.62 & 37.35 & 8.90 & 12.81 & 1.53 & 1.59 & 42.26 & 40.00 & 10.68 & 20.14 \\
\hline $\mathbf{K}$ & 1.58 & 1.64 & 40.37 & 38.11 & 6.97 & 10.03 & 1.51 & 1.57 & 43.01 & 40.75 & 8.36 & 16.66 \\
\hline $\mathbf{L}$ & 1.55 & 1.62 & 41.50 & 38.86 & 5.52 & 7.94 & 1.48 & 1.55 & 44.15 & 41.50 & 6.62 & 15.77 \\
\hline
\end{tabular}

1st: The physical properties determined after 3 days of planting. 2nd: The physical properties determined after 40 days of planting.

Under studied treatments, the lowest soil bulk density value was 1.38 and $1.40 \mathrm{~g} / \mathrm{cm}^{3}$ for double disc furrow with drag chains treatment at the first irrigation after 3 days and after 40 days of the planting date of the corn silage, respectively. At the same treatments, the highest value of soil bulk density was 1.32 and $1.34 \mathrm{~g} / \mathrm{cm}^{3}$ for double disc furrow with drag chains treatment at the first irrigation after 3 days and after 40 days of the planting date of the pea plants, respectively. The obtained results revealed that the soil bulk density values at the first irrigation after 3 days 
and after 40 days of the planting date of the pea plants under studied treatments were lower than that obtained under corn silage at the same treatments. These lower might be attributed to the effect of some residual corn plants in soil throughout the pea growth season. This effect relatively increased the organic matter, consequently, decreasing soil compaction.

Total soil porosity percentages of the cultivated surface soil depth at the first irrigation after 3 days and after 40 days of the planting date during corn silage and pea plants growth seasons affected by combination between the furrow openers and covering devices were more than the initial of the experimental soil, Table (1). The soil porosity values at the first irrigation after 3 days and after 40 days of the planting date at corn silage growth season under studied treatments varied between 39.62 to $47.92 \%$ and $38.87-47.17 \%$, respectively. While, the soil porosity values at the first irrigation after 3 days and after 40 days of the planting date of pea growth season at the same treatments varied $42.26-50.19 \%$ and $40.00-49.43 \%$, respectively.

The comparative effect of the furrow opener devices on total porosity of cultivated surface soil depth during growth season of studied crops showed that the double disc furrow opener had the highest soil porosity percentage values. Consequently, the soil water content and aeration at the active root depth will be increased. The soil porosity percentages for cultivated surface soil depth at studied furrow opener devices during studied growth season of corn and pea were ranked as double disc > single disc $>$ shoe $>$ hoe. This ranked might be attributed to the double disc furrow opener decreased the soil compaction. Thus, the soil porosity percentage values and aeration increased. The comparative effect of the seed covering devices on the soil porosity of cultivated surface soil depth during growth season of studied crops elucidated that the drag chains had the highest soil porosity percentage values and ranked as drag chains > paddles > wheel. Also, the obtained results showed that soil porosity values after 40 days of the planting date of the corn silage and pea were lower than that obtained at the first irrigation after 3 days under studied treatments. This lower could be attributed to the wetting and drying cycles during 40 days from planting days increased soil compaction, 
consequently, increasing bulk density. Under studied treatments, the soil porosity highest value was 47.92 and $47.17 \%$ for double disc furrow with drag chains treatment at the first irrigation after 3 days and after 40 days of the planting date of the corn silage, respectively. At the same treatments, the highest value of soil porosity was 50.19 and $49.43 \%$ for double disc furrow with drag chains treatment at the first irrigation after 3 days and after 40 days of the planting date of the pea, respectively. Furthermore, the obtained results indicated that the soil porosity values at the first irrigation after 3 days and after 40 days of the planting date of the pea under studied treatments were higher than that obtained under corn silage. These higher might be attributed to the effect of some residual corn plants in soil during the pea growth season. This effect relatively increased the organic matter in the soil, consequently, decreasing the soil bulk density and increment soil porosity.

The comparative effect of the furrow opener devices on soil water content values of cultivated soil depth elucidated that the double disc furrow opener had the highest soil water content values during growth season of studied crops, Table (1). The soil water content values for cultivated soil depth at studied furrow opener devices during corn silage and pea growth seasons were ranked as double disc $>$ single disc $>$ shoe $>$ hoe. This trend might be attributed to the double disc furrow openers decreased soil bulk density thus, the soil porosity increased. Also, this trend is similar that obtained for soil porosity under the same treatments. The comparative effect of the seed covering devices on the soil water content values of cultivated soil depth during corn silage and pea growth seasons revealed that the wheel had the highest soil water content values and ranked as wheel $>$ paddles $>$ drag chains. This trend was opposite for that obtained at the same treatments. Also, the obtained results indicated that soil water content values after 40 days of the planting date of the corn silage and pea were higher than that obtained at the first irrigation after 3 days under studied treatments. This higher could be due to the reorientation of soil particles and increasing soil porosity resulting by the wetting and drying cycles during 40 days from planting days. Under studied treatments, the highest value of soil water content was 18.78 and $27.03 \%$ for double disc furrow with wheel treatment at the first irrigation 
after 3 days and after 40 days of the planting date of the corn silage, respectively, Table (1). At the same treatments, the highest value of soil water content was 22.53 and $31.26 \%$ for double disc furrow with wheel treatment at the first irrigation after 3 days and after 40 days of the planting date of the pea, respectively. The soil water content values at the first irrigation after 3 days and after 40 days of the planting date of the pea under studied treatments were higher than that obtained under corn silage. These higher might be attributed to the effect of some residual corn plants in soil during the pea growth season. This effect may be relatively increased the organic matter in the soil, consequently, increasing the soil water retention.

\section{Effect of furrow openers and covering devices on consumed energy of planting operation.}

The consumed energy of planting operation values under studied treatments of corn silage and pea were illustrated in Fig. (2). The obtained results revealed that the higher fuel consumption of planting operation was observed at hoe furrow opener as compared with the other studied treatments for corn silage and pea. These results indicated that the consumed energy of planting operation values at studied furrow opener devices were ranked as hoe $>$ shoe $>$ double disc $>$ single disc. This trend could be explained for both hoe and shoe furrow openers had more soil-metal friction and exerted higher force with soil pattern and the horizontal component of the force exerted by the blades surface area. Consequently, the hoe and shoe blades required higher energy as compared to the disc blades under the same conditions. The obtained results showed that the consumed energy of seeding operation values at studied covering devices for planting operation of corn silage and pea crops were ranked as drag chains > paddles > wheel, Fig. (2). The consumed energy of planting operation values for studied furrow opener devices under studied crops may be expected higher than that obtained for studied seed covering devices. Thus, the major effect on consumed energy of seeding operation values could be due to the furrow openers (blade types), while the minor effect could be due to the seeding covering devices. This effect might be attributed to the hoe and shoe shaped blades 
penetrate the soil slice off almost entirely along of the lateral planes throughout the full depth of the blade, while the disc blades partly penetrate and partly tore the soil slice along vertically with less soil resistance. These results were in agreement with the finding of Magdy (1998). The obtained results in figure (2) reveal that the energy values varied between 35.65 to $51.02 \mathrm{~kW}$. h /fed and 31.93 to $45.73 \mathrm{~kW}$. h/fed for corn silage and pea plants under studied treatments, respectively. Generally, the values of consumed energy of planting operation for corn silage were higher than that obtained for pea. This higher values might be attributed to the effect of some residual corn plants in soil at the planting operation of pea plants. This effect may be relatively increased the organic matter in the soil and decreasing soil compaction. Consequently, the values of consumed energy for planting operation at pea plants decreased.

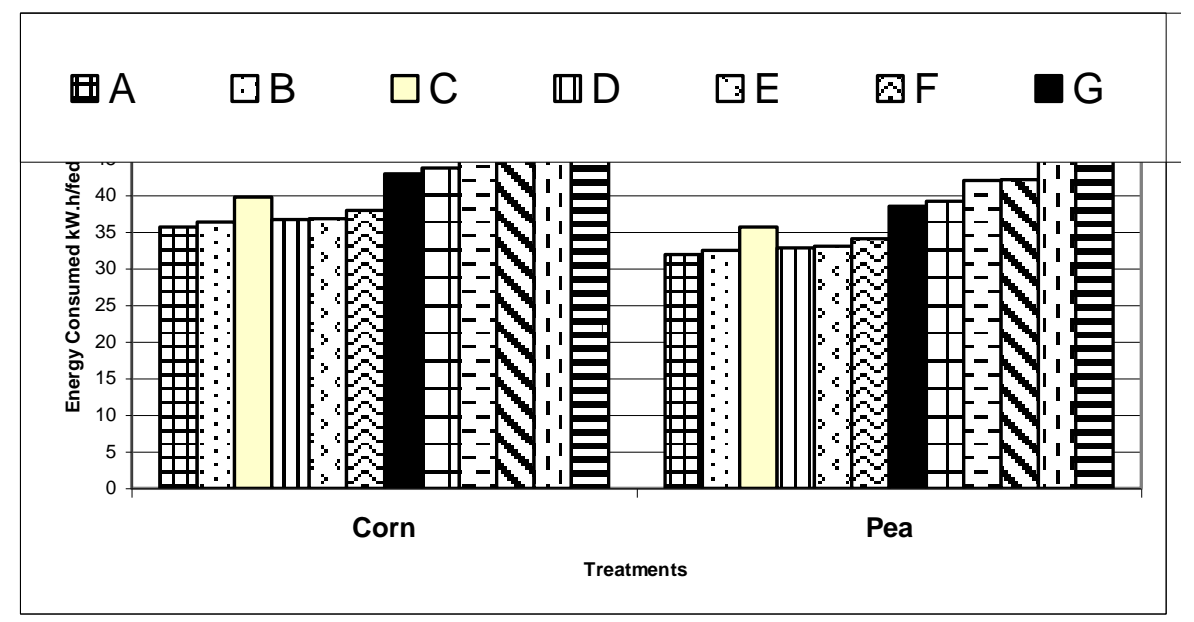

Fig. (2): Effect of furrow openers and covering devices on energy consumed.

\section{The comparative effect of furrow openers and seed covering devices} on seed germination percentage and Biological yield.

The comparative effect of the furrow opener devices on seed germination values revealed that the double disc furrow opener had the highest values for corn silage and pea as shown in table (2). The seed germination percentage values of corn silage and pea under studied furrow opener devices were ranked as double disc $>$ single disc $>$ shoe $>$ hoe. This trend 
might be attributed to the double disc furrow opener increased the soil porosity and aeration. The comparative effect of the seed covering devices on the seed germination percentage values of corn silage and pea showed that the wheel had the highest values and ranked as wheel > paddles $>$ drag chains. The obtained results in table (2) revealed that the seed germination percentage values ranged between 94.0 to $81.0 \%$ and 98.2 to $86.0 \%$ for corn silage and pea plants under studied treatments, respectively. The seed germination values of corn silage and pea under studied furrow openers and seed covering devices were appeared significantly affect with $\mathrm{LSD}_{05}$ values were 2.97 and 2.83 , respectively. Also, the obtained results showed that the seed germination percentage highest value was $94.0 \%$ and $98.2 \%$ at double disc furrow with wheel treatment for the corn silage and pea under studied treatments, respectively. At the same treatments, the lowest value of seed germination percentage for corn silage and pea was 81.0 and $86.0 \%$ at hoe furrow with drag chains treatment, respectively.

The comparative effect of the furrow opener devices on yield values of corn silage and pea, $\mathrm{kg} / \mathrm{fed}$, revealed that the double disc furrow opener had the highest values. The total biological yield values of corn silage and pea under studied furrow opener devices were ranked as double disc $>$ single disc $>$ shoe $>$ hoe. This trend might be attributed to the double disc furrow opener disturbed the soil particles, consequently, the soil porosity and soil water content increased as well as the productivity of crops increased. Generally, the comparative effect of the seed covering devices on the yield values of corn silage and pea were demonstrated significant affect as clarified in table (2). Also, the obtained results showed that the wheel had the highest yield values of studied crops. The comparative effect of the seed covering devices on the yield values of corn silage and pea were ranked as wheel > paddles $>$ drag chains. The obtained results revealed that the total biological yield values of corn silage and pea varied 39260 to $20410 \mathrm{~kg} / \mathrm{fed}$ and 5299 to $815 \mathrm{~kg} / \mathrm{fed}$ under studied treatments, respectively. Furthermore, the total biological yield values of corn silage and pea under studied furrow openers and seed covering devices were appeared significantly affect with LSD $_{05}$ 
value was 1589 and 792, respectively. Under studied treatments, the obtained results in table (2) showed that the highest biological yield value of corn silage and pea was 39260 and $5299 \mathrm{~kg} / \mathrm{fed}$ at double disc furrow opener with wheel treatment, respectively. This might be due to the effect of the discs and wheels for the penetration into the soil profile could be considered suitable to the optimum levels of seedbed as compared to the other furrow openers and seed covering devices consequently, seedling emergence, vegetation growth and crop yield were relatively high. These results are in agreement with Khater, (2010). At the same treatments, the lowest biological yield value of corn silage and pea was 20410 and 815 $\mathrm{kg} /$ fed were found at hoe furrow opener with drag chains treatment, respectively.

Table (2): The comparative effect of furrow openers and seed covering devices on seed germination percentage and yield.

\begin{tabular}{|c|c|c|c|c|}
\hline \multirow{2}{*}{ Treatments } & \multicolumn{2}{|c|}{ Corn silage } & \multicolumn{2}{c|}{ Pea } \\
\cline { 2 - 5 } & $\begin{array}{c}\text { Seed } \\
\text { Germination }\end{array}$ & $\begin{array}{c}\text { Biological } \\
\text { Yield } \\
(\mathbf{K g} / \mathbf{f e d})\end{array}$ & $\begin{array}{c}\text { Seed } \\
\text { Germination }\end{array}$ & $\begin{array}{c}\text { Biological } \\
\text { Yield } \\
(\mathbf{K g} / \mathbf{f e d})\end{array}$ \\
\hline A & 90.7 & 32500 & 95.1 & 13460 \\
B & 90.5 & 31070 & 95.0 & 13445 \\
C & 90.5 & 28210 & 95.0 & 13344 \\
D & 94.0 & 39260 & 98.2 & 15299 \\
E & 93.0 & 36010 & 97.3 & 15075 \\
F & 92.3 & 34710 & 96.6 & 13660 \\
G & 87.4 & 28080 & 92.0 & 12129 \\
H & 87.4 & 27300 & 92.0 & 12112 \\
I & 85.4 & 27040 & 90.1 & 12005 \\
J & 85.4 & 26780 & 90.0 & 11915 \\
K & 84.2 & 24440 & 89.0 & 10830 \\
L & 81.0 & 20410 & 86.0 & 10815 \\
\hline LSD 0.05 & $\mathbf{2 . 9 7}$ & $\mathbf{1 5 8 9 . 0 0}$ & $\mathbf{2 . 8 3}$ & $\mathbf{7 9 2 . 0 0}$ \\
\hline
\end{tabular}




\section{CONCLUSION}

The soil bulk density of the cultivated surface soil depth $(0-15 \mathrm{~cm})$ at 3 and 40 days after the planting date of corn silage (Zea mays) and pea (Pisum sativum ) with studied treatments combined between the furrow openers and seed covering devices under sprinkler irrigation system were lower than that the initial soil. Under studied treatments, the highest value of soil porosity was found at double disc furrow with drag chains treatment. While, the highest value of soil water content was found for double disc furrow with wheel treatment. Under the same treatments, in general, the values of consumed energy of seeding operation for corn silage were higher than that for pea plants. The consumed energy of seeding operation values for studied furrow opener devices under both crops may be expected higher than that for covering devices. Thus, the major effect on consumed energy of seeding operation values could be due to the furrow openers (blade types), while the minor effect could be due to the covering devices. The highest value of seed germination and biological yield for corn silage and pea plants was at double disc furrow opener with wheel treatment. This result is corresponded with the result of soil water content. Consequently, the using double disc furrow opener with wheel treatment at seeding operation is preferable treatment for the increasing the productivity of studied crops. This treatment is caused the disturbing of soil aggregates, decreasing of soil compaction, increasing soil porosity and soil water content.

\section{REFERENCES}

Ashworth, M.; J. Desbiolles, and E. Tola (2010). Disc Seeding in Zerotill Farming Systems: A Review of Technology and Paddock Issues. Western Australian No-Tillage Farmers Association, Northam, Western Australia. 224 pp.

Chen, Y.; S. Tessier and B. Irvine (2006). Drill and crop performance as affected by different drill configurations for no-till seeding. Soil and Tillage Res., Vol.77, 147-155. 
Chaudhuri, D. (2001). Performance evaluation of various types of furrow openers on seed drills. A. Review. J. Agric. Eng. Res. 79 (2), $125-137$

Giles, J. F.; A.W. Cattanach and N. R. Cattanach (1995). Effect of seedbed moisture management on sugar beet stand establishment, yield and quality. Proceedings of the $58^{\text {th }}$. Winter Congress International Institution of Sugar Beet Research, p. 521- 522.

Hunt R. D. (ed.) (1983). Farm Power and Machinery Management. $9^{\text {th }}$., Cushing-Malloy Inc., NY.

Khater, M. M. I. (2010). Comparison study between some minimum tillage systems in sandy loam soil. Egyptian. J. Appl. Sci., 20 (5): 286-296

Klute, A. (ed.) (1986). Methods of Soil Analysis. Part 1. Physical and Minerological Properties. Am. Soc. Agron. Inc., Agronomy Series 9. USA. 1173 pp.

Magdy, A. A. M. (1998). Cotton mechanical planting parameters in new land. M.Sc. Thesis, Fac. Agric., Zagazig Univ., Egypt.

Murray J. R.; J. N. Tullberg and B. B. Basnet (2006). Planters and Their Components Types, Attributes, Functional Requirements, Classification and Description. ACIAR Monograph No.121. 306 pp.

Rainbow, R. (2008). Integration of No-till and Precision Agriculture Technologies and future Challenges to Conservation Agriculture in Australia. In: Goddard, et al. (eds), No-till Farming System. Special publication No.3, World Association of Soil and Water Conservation, Bangkok. p. 974-982.

Robert, G.; H. David and P. Robert (2009). Equipment Considerations for No-till Soybean Seeding. Virginia Cooperative Extension Programs. publication 442-456.

Steel, R. G. D., and J. H. Torrie. (1980). Principles and Procedures of Statistics. McGraw-Hill, New York. 
الملخص العربى

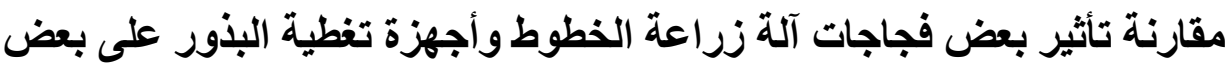 خواص التربة و إنتاجية بعض التهو المحاصيل \\ * إسلام محمد منير خاطر}

أجريت الدر اسة على الة الزر اعة فى خطوط لإنتاج ذرة العلف (السيلاج) و البسلة فى تربة رملية

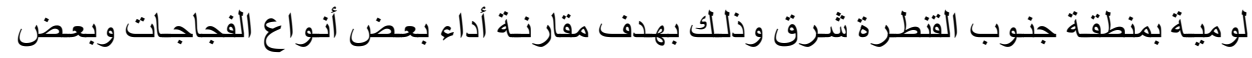
اجهزة التغطية على بعض خو اص التربة و الطاقة المستهلكة ونسبة الإنبات و إنتاجيـة المحاصيل.

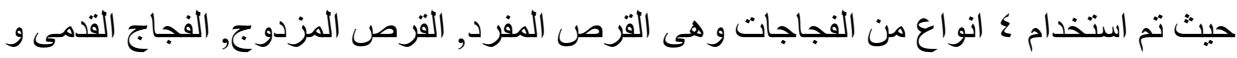

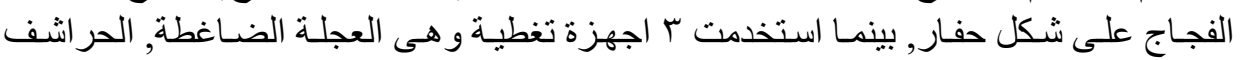

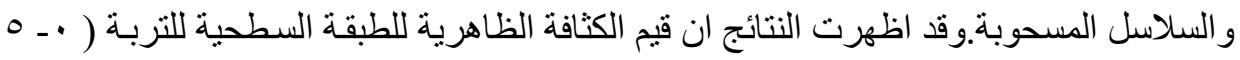

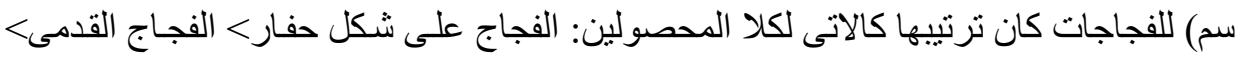

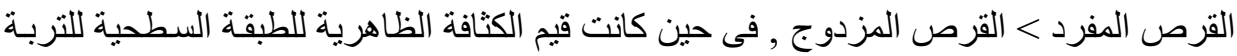

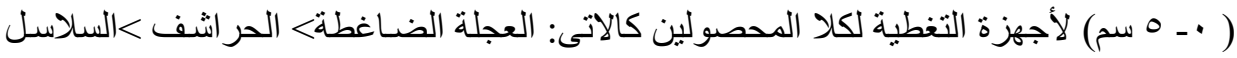

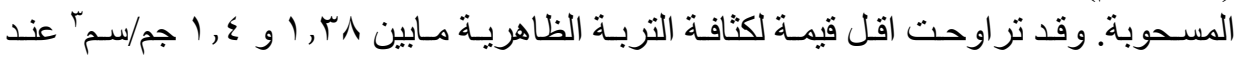

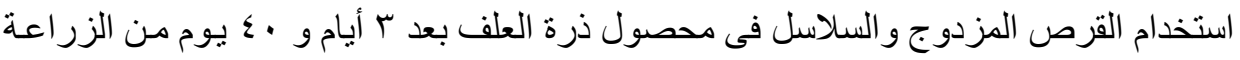

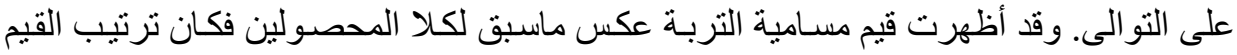

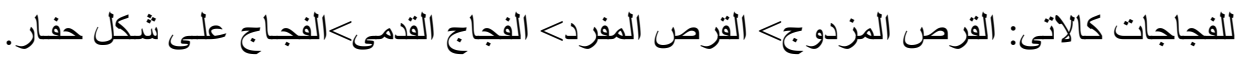

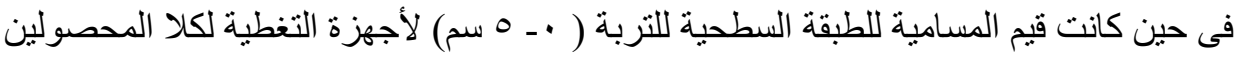

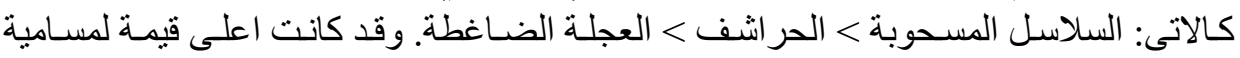

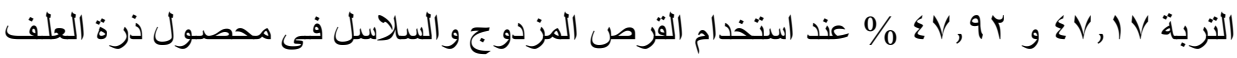

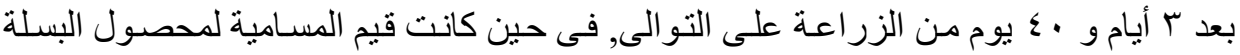

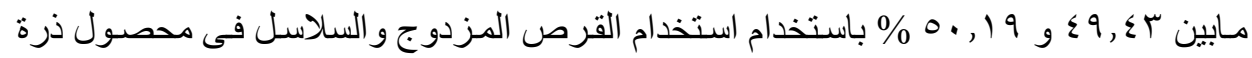

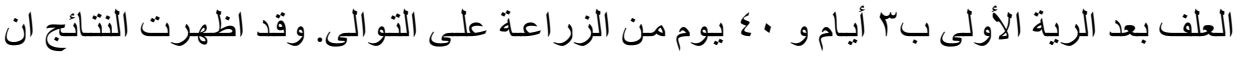

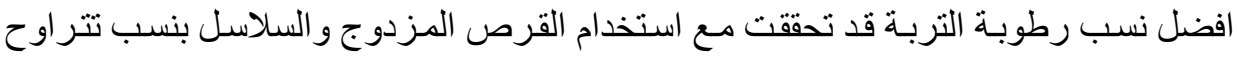

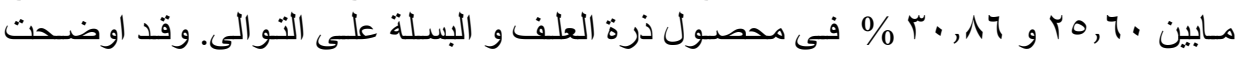

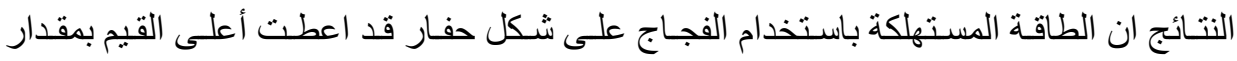

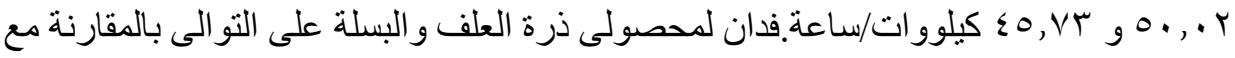

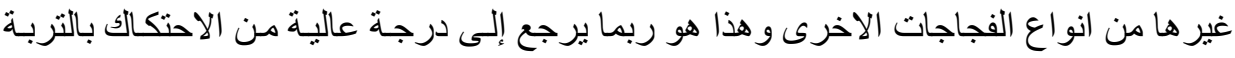

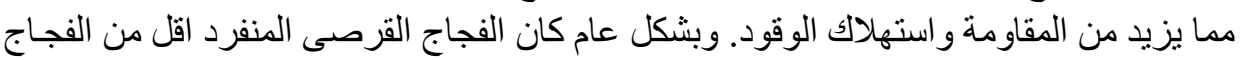

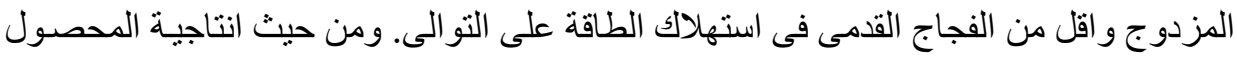

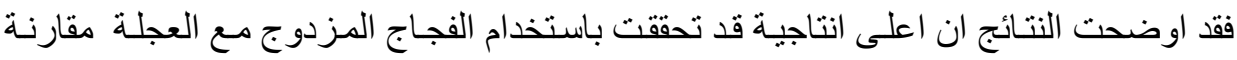

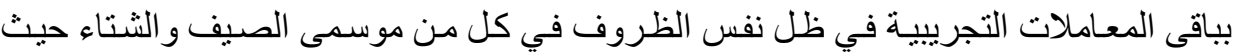

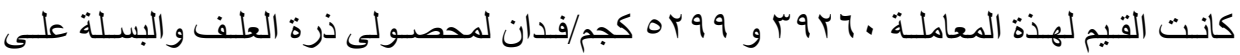
التو الى. 